\title{
PNEUMOCONIOSIS OF COAL MINERS IN NORTH EAST ENGLAND WITH SPECIAL REFERENCE TO THE DURHAM COALFIELD
}

\author{
BY \\ R. I. McCALLUM \\ From the Nuffield Department of Industrial Health, University of Durham (King's College, Newcastle upon Tyne)
}

(RECEIVED FOR PUBLICATION FEBRUARY 2, 1952)

The true prevalence of coal miners' pneumoconiosis in north east England is unknown and this paper attempts to answer the following questions from existing evidence : (1) What is the past history of the disease in this area and how did it relate to mining practice? (2) What is the present prevalence and how does the type of disease vary with the age of the miner, and (3) is there a case for a pneumoconiosis survey in this coalfield?

From the earliest times coal has come from Newcastle (Nef, 1932). At the turn of the eighteenth century the introduction of the steam engine for pumping, winding, ventilation, and haulage led to the rapid expansion of the coal mining industry. The bord and pillar system, in which a series of narrow headings are driven into a seam parallel to one another and connected by cross headings, is more widely used in Durham than elsewhere, and mechanization has come more slowly here than in the rest of England (Smith, 1949).

John Evelyn, in his "Fumifugium" published in 1661 , wrote that :

" Newcastle Cole, as an expert Physician affirms, causeth consumptions, phthisicks and the indisposition of the lungs, not only by the suffocating aboundance of smoake, but also by its virulency, for all subterrany fuel hath a kind of virulent or arsenical vapour rising from it ; which, as it speedily destroys those who dig it in the mines, so does it, by little and little, those who use it here above them."

This suggests that at this time coal miners suffered from chest disease.

Gregory (1831) and Thomson (1837) first reported "black lungs" in Great Britain, but at this time only one proven case (Stratton, 1838) had been seen in Newcastle. In $1861 \mathrm{Sir}$ John Simon mentioned that Northumberland and Durham miners were free from excess of pulmonary disease and suggested that this was due to good ventilation of their pits.
In 1866 and 1869 Greenhow demonstrated to the Pathological Society of London cases of colliers' black lung among miners from the Newcastle area. Oliver (1908) stated that cases of miners' phthisis were common in the Newcastle Infirmary towards the end of the nineteenth century, but he said that since the turn of the century very few cases had been seen. It appears then, that in the latter half of the nineteenth century what is now called the complicated form of miners' pneumoconiosis (Fletcher and Gough, 1950) was being recognized, but that at the beginning of the twentieth century it had almost disappeared. By the end of 1933 no miner from Durham had been certified as suffering from pneumoconiosis and only one from Northumberland, compared with 500 from Wales.

In 1943 the Workmens Compensation Act was extended to include earlier lung changes (dust reticulation). Table 1 (from McVittie, 1949) shows the number of men certified from 1939 to June, 1948, before the National Insurance (Industrial Injuries) Act took the place of the workmen's compensation acts, and demonstrates the great increase in certifications following the extended scope of this legislation.

The increase appears everywhere, but the total numbers in Northumberland, Durham, and Cumberland combined, are very small compared with Wales and the rest of the British Isles.

Figures published in 1948 by the National Union of Mineworkers (Durham Area), which, however, refer only to men whose application had been made through the Union, show (Fig. 1) an increase in the number of applications and successful claims between 1943 and 1948 in County Durham. Most of the men who made claims were face workers and half of them were successful. 
TABLE 1

NEW CASES CERTIFIED BY THE SILICOSIS MEDICAL BOARD FROM 1939 TO JUNE 30, 1948*

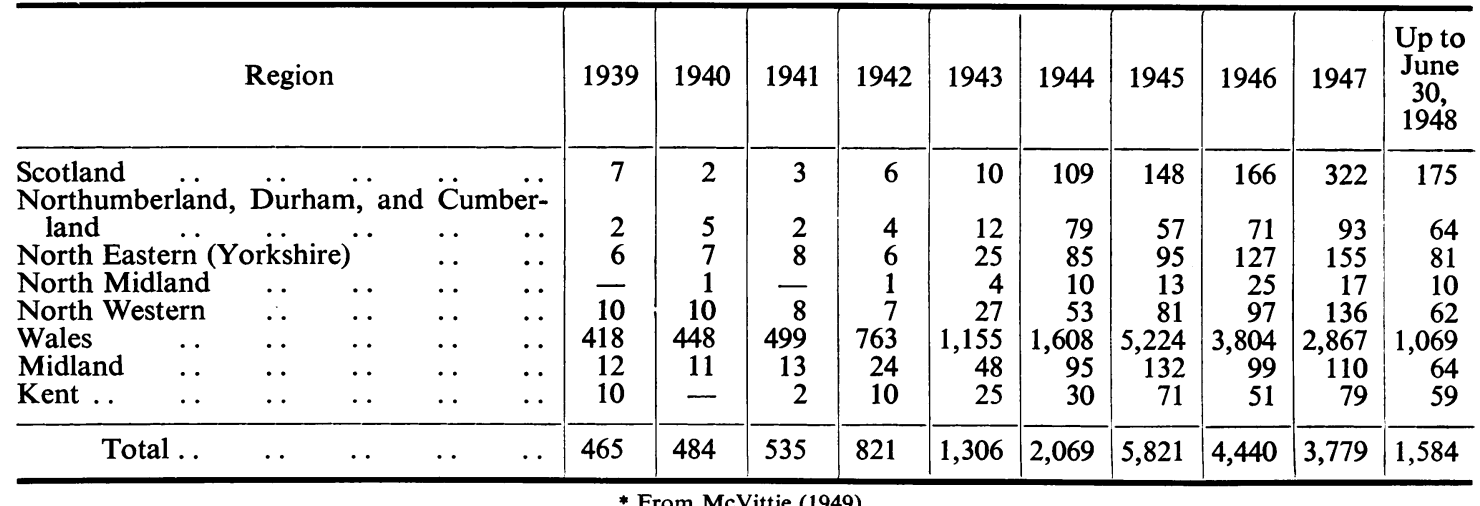

* From McVittie (1949).

The steady rise in the certification figures, notwithstanding their limitations, suggests a rise in prevalence or an increased local awareness of the disease, or a combination of both. During this period the greatest number of certified cases tended to be in the large modern pits near the coast, but collieries with a small number of certified cases were scattered widely over County Durham (Fig. 2). In Northumberland at the same time six men died of the disease and 41 were certified, most of them partially disabled.

\section{The Recent and Present Position}

Out-Patient Experience.-When the Nuffield Department of Industrial Health opened a clinic in Newcastle upon Tyne early in 1947 it was clear that a major local problem was the dyspnoeic coal miner. A study of the first 100 patients seen by Browne, Beck, and McCallum (1949) showed that 69 were coal miners, most of them with chest symptoms. Twenty-one men, all of them face workers, had pneumoconiosis, 16 with the simple and five with the complicated disease. The radiological changes were similar to those described in South Wales coal miners by Hart and Aslett (1942) and by Davies and Mann (1949).

Attention was further drawn to the problem when between March and July, 1948, 21 drillers from a Durham pit were examined at their own request because four of their workmates had recently been certified as suffering from pneumoconiosis. All of them had been drilling in both coal and stone for 13 to 32 years at the same pit. Fourteen men had abnormal chests. One man had pulmonary tuberculosis, probably active, and the remaining 13 pneumoconiosis, one of them the complicated type. Nine of these men were symptomless when first seen, and two of four men with shortness of breath and cough had had their symptoms over two years. Subsequently five of these drillers were granted compensation. Their ages ranged from 37 to 56 with an average of 49 years.

During the three years since the clinic was opened more than 300 coal miners with pneumoconiosis have been seen. Most of the men come from County Durham but there have been a few from Northumberland. A large number, many referred by their own doctors after mass miniature radiography, had no symptoms.

\section{Pneumoconiosis Certification}

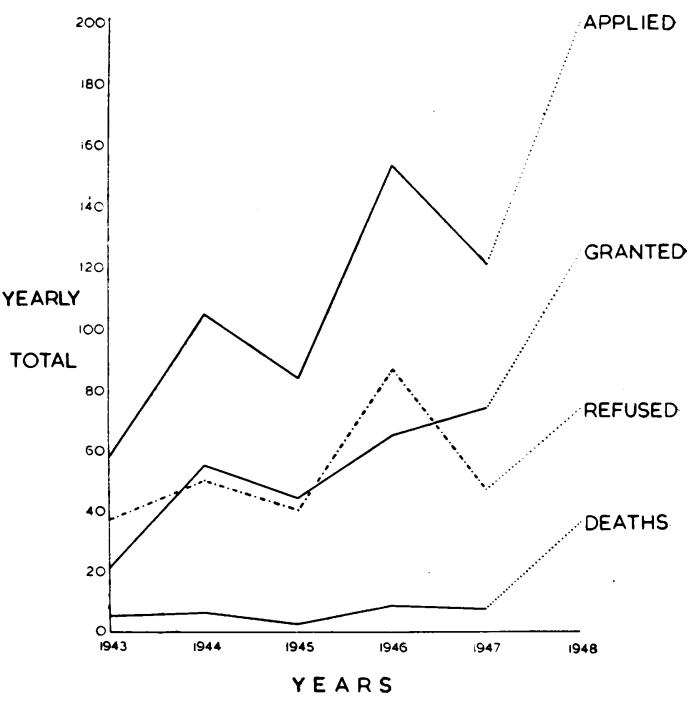

FIG. 1-Pneumoconiosis certification in County Durham between 1943 and 1948 (July). As the figures for 1948 are available only up to July 5 , the graph has been continued as if the same rate were maintained to the end of the year (dotted line). 


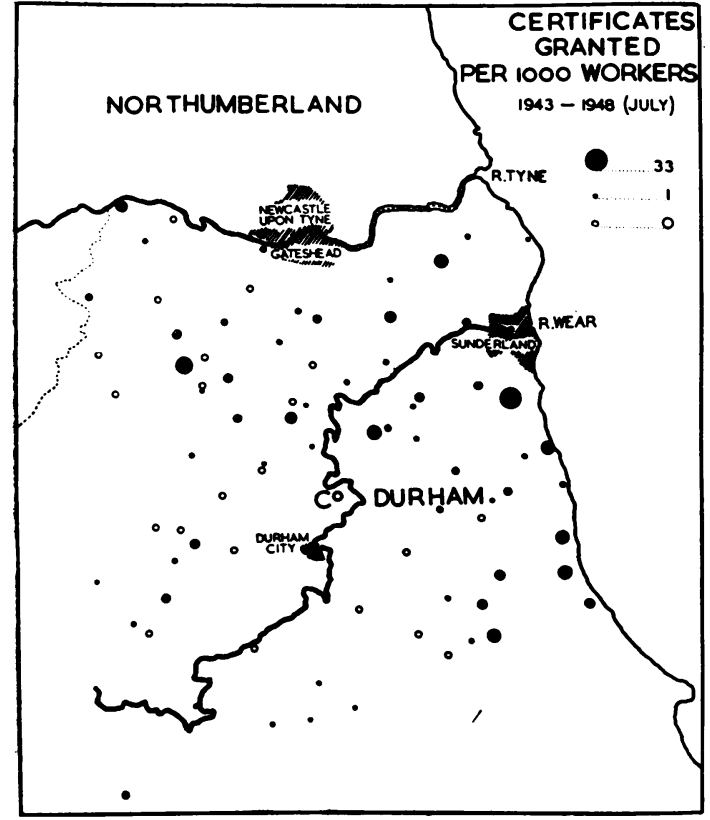

FIG. 2.-Distribution of certified cases of pneumoconiosis per 1,000 workers in the Durham coalfield in 1943-48.

The Limitations of Mass Miniature Radiography

Notwithstanding their limitations, the results of mass miniature radiography provide the only evidence of the prevalence of pneumoconiosis in this area, for the number of certified cases can be misleading in deducing the prevalence of pneumoconiosis in all its forms (Cochrane, 1951). These results should therefore be considered with reservations.

In August, 1948, a mass miniature radiography (M.M.R.) unit started work in the pits of County
Durham. The examination was voluntary and primarily designed to detect cases of pulmonary tuberculosis. In the first year of its work eight pits were visited. It was soon obvious that pulmonary tuberculosis was not the main problem but that a number of miners had pneumoconiosis.

Response of Volunteers.-Forty-four to $61 \%$ of the men at the different pits visited volunteered for $x$-ray examination. It is difficult to say what determines who comes forward, because experience with out-patients shows that men with bronchitis and emphysema have similar symptoms to those of dust disease, while other men with simple or even complicated pneumoconiosis may have no symptoms at all. In some pits there was an atmosphere of suspicion lest the examination was designed to weed out men with " dust" with a view to discharging them, despite the repeated assurance that the examination was confidential. Thus some men who thought they had pneumoconiosis may have been discouraged from attending and others who thought they were in good health may have considered that it was unnecessary for them to be examined.

The ages of all men attending the M.M.R. unit for a miniature film at three collieries between March and August, 1949, are known, and the distribution of age was compared with that of all the men in each of the three collieries, using figures obtained from the National Coal Board of a manpower survey made in December, 1948. It was assumed that the age pattern would not have altered materially over a few months (Table 2). In this table there is no systematic change in the percentage of volunteers with age; but as age increases there is an increase in dyspnoea from all causes and a presumed increase in pneumoconiosis. It is unlikely, therefore, that the presence of dyspnoea

TABLE 2

NUMBER OF MEN IN EACH OF THREE COLLIERIES ATTENDING FOR MINIATURE FILMS COMPARED BY AGE TO TOTAL NUMBER OF MEN ON COLLIERY BOOKS

\begin{tabular}{|c|c|c|c|c|c|c|c|c|c|}
\hline \multirow{3}{*}{ Age } & \multicolumn{3}{|c|}{ Colliery E } & \multicolumn{3}{|c|}{ Colliery F } & \multicolumn{3}{|c|}{ Colliery $\mathbf{H}$} \\
\hline & \multirow{2}{*}{$\begin{array}{l}\text { No. of } \\
\text { Men }\end{array}$} & \multicolumn{2}{|c|}{ Miniature Films } & \multirow{2}{*}{$\begin{array}{l}\text { No. of } \\
\text { Men }\end{array}$} & \multicolumn{2}{|c|}{ Miniature Films } & \multirow{2}{*}{$\begin{array}{l}\text { No. of } \\
\text { Men }\end{array}$} & \multicolumn{2}{|c|}{ Miniature Films } \\
\hline & & No. & $\%$ & & No. & $\%$ & & No. & $\%$ \\
\hline 19 and & 147 & 47 & 32 & 163 & 62 & 38 & 156 & 62 & 40 \\
\hline $\begin{array}{c}20-29 \\
30-39 \\
40-49 \\
50-54 \\
55-59 \\
60 \text { and } \\
\text { over }\end{array}$ & $\begin{array}{r}347 \\
289 \\
277 \\
107 \\
88 \\
80\end{array}$ & $\begin{array}{r}210 \\
185 \\
196 \\
70 \\
55 \\
48\end{array}$ & $\begin{array}{l}61 \\
64 \\
71 \\
65 \\
63 \\
60\end{array}$ & $\begin{array}{l}429 \\
440 \\
460 \\
170 \\
171 \\
141\end{array}$ & $\begin{array}{r}220 \\
246 \\
292 \\
95 \\
76 \\
72\end{array}$ & $\begin{array}{l}51 \\
56 \\
63 \\
56 \\
44 \\
51\end{array}$ & $\begin{array}{l}338 \\
445 \\
430 \\
138 \\
104 \\
125\end{array}$ & $\begin{array}{r}164 \\
199 \\
260 \\
106 \\
57 \\
42\end{array}$ & $\begin{array}{l}49 \\
45 \\
60 \\
77 \\
55 \\
34\end{array}$ \\
\hline Total & 1,335 & 811 & 61 & 1,974 & 1,063 & 54 & 1,736 & 890 & 51 \\
\hline
\end{tabular}


or pneumoconiosis has influenced volunteering to any great extent. lem was the unknown number of men with early degrees of pneumoconiosis who might be overlooked in viewing the miniature films. At each pit the men were first examined by miniature films which were viewed by the director of the M.M.R. unit, who had no special experience of pneumoconiosis. Those thought to be abnormal in any way were recalled for a large film. It was unlikely that he was able to detect Category 1 changes from a miniature film. Category 2 changes might or might not be detectable on certain miniature films ; and only for Category 3* changes could a definite opinion be given that pneumoconiosis was present. Many lungs which appear abnormal on miniature films because of prominent vascular shadows are found to show no pneumoconiosis when a full size film is taken, and others might show early opacities due to dust. The difficulties of classifying the large films are sufficiently great to make classification of small films a waste of time.

A test was carried out with 102 consecutive miniature films of miners at the same pit and large films of the same men. The miniatures were classified by one observer and the results compared with a classification of the large films by the same observer reading with another observer using a
Diagnosis from Miniature Films.-Another prob-

Experience in South Africa, where mass miniature radiography has been used extensively for native labourers, has been that miniature films tend to exaggerate abnormal shadows such as tubercular lesions but that there is difficulty in reading the miniatures of early silicosis (Retief, 1946). It appears that only full size films are likely to be of use in detecting pneumoconiosis in coal miners, where the choice lies between them and the miniature $(35 \mathrm{~mm}$.) film. We have, therefore, not used the miniature films for categorization. Only the large films have been considered. These were only available in a small proportion of the cases-about $10 \%$ of the total number of men in the pits.

Viewing.-Two observers examined the large films on a standard viewing box. Sessions were kept short to avoid fatigue and lasted from threequarters to one hour, and the final category had to be agreed by both observers. Where there was doubt, a number of reference films which had been classified by members of the Pneumoconiosis Research Unit in Cardiff, using their system (Fletcher, Mann, Davies, Cochrane, Gilson, and Hugh-Jones, 1949), were used as a standard (Fletcher and Oldham, 1949, 1951). These reference films had been taken at a Durham colliery with the same machine and technique as that used for the films being classified. A copy of Davies and Mann's (1949) paper, which describes each category, was

TABLE 3

COMPARISONS OF READINGS OF LARGE AND MINIATURE FILMS OF THE SAME SUBJECTS AT A DURHAM PIT

\begin{tabular}{|c|c|c|c|c|c|c|c|}
\hline \multirow{4}{*}{ Large Films : Observers A and B } & \multirow{2}{*}{ Category } & \multicolumn{6}{|c|}{$\begin{array}{l}\text { Miniature Films : Observer B } \\
\text { Category }\end{array}$} \\
\hline & & 0 & 1 & 2 & 3 & 4 & Total \\
\hline & $\begin{array}{l}0 \\
1 \\
2 \\
3 \\
4\end{array}$ & $\begin{array}{r}25 \\
10 \\
2 \\
1 \\
-\end{array}$ & $\begin{array}{r}4 \\
1 \\
- \\
-\end{array}$ & $\begin{array}{r}18 \\
6 \\
7 \\
12 \\
\end{array}$ & $\begin{array}{l}1 \\
3 \\
3 \\
7 \\
2\end{array}$ & - & $\begin{array}{r}48 \\
20 \\
12 \\
20 \\
2\end{array}$ \\
\hline & Total & 38 & 5 & 43 & 16 & - & 102 \\
\hline
\end{tabular}

standard set of categorized films. It will be seen from Table 3, assuming that the reading of the large films was correct, that 35 miniatures were placed in too high a category, 27 in too low a category, and in only 40 was there agreement. Also, of the 48 cases with normal large films (Category O), 19 were placed more than one category higher in the corresponding miniature films. Thus the tendency was to read higher on the miniature films, and it appears that miniature films are likely to be misleading in a survey to detect simple pneumoconiosis in all its stages.

also available for reference. One of the two observers had visited the Cardiff unit and had seen the method in use.

Each film was viewed without knowing the man's age or occupational history, and the category was entered on to his history sheet by a clerk to eliminate bias from a knowledge of the working history. With good quality films there was usually no difficulty in classifying from Category 3 upwards, but the variation within Categories 1 and 2 appears to be rather greater than in the higher categories and small differences in film quality made classification more difficult and less consistent. This was 
intensified by the difficulty encountered with fluctuations in current supplies at some collieries, resulting in underpenetrated films.

Amongst the most difficult tasks in using the Davies and Mann classification was the differentiation between a normal film and the earliest detectable changes due to dust, Category 1 . This was particularly hard in the somewhat soft films used in these surveys as the normal vascular shadows tended to obscure the smaller details of the lung fields. For this reason, and as a check on the general suitability of the classification for use in coalfields other than South Wales and by different observers, a comparison was made between two readings by Newcastle observers and two readings by members of the Pneumoconiosis Research Unit in Cardiff of the same set of 64 large films taken by the Durham M.M.R. unit and selected from Categories 0 to 2. Two of these films were rejected as unreadable by the Cardiff observers and have not been included in the results in Table 4. These readings showed that the Newcastle observers tended to place the films in somewhat higher categories and were less consistent than the Cardiff observers, but the difference was not gross.
TABLE 4

COMPARISON OF READINGS* OF 64 LARGE FILMS BY CARDIFF (P.R.U.) AND NEWCASTLE OBSERVERS

\begin{tabular}{c|c|c|c|c}
\hline \multirow{2}{*}{ Category } & \multicolumn{2}{|c|}{$\begin{array}{c}\text { Newcastle } \\
\text { Observers }\end{array}$} & \multicolumn{2}{c|}{$\begin{array}{c}\text { Cardiff (P.R.U.) } \\
\text { Observers }\end{array}$} \\
\cline { 2 - 5 } & A \& B & A \& C & D & E \\
\hline 0 & 31 & 27 & 38 & 40 \\
1 & 31 & 27 & 23 & 20 \\
2 & 0 & 8 & 1 & 2 \\
\hline Mean category & 0.50 & 0.69 & 0.40 & 0.39 \\
\hline
\end{tabular}

* Films were read twice in each centre. Cardiff observers read the films on separate occasions, Newcastle observers in pairs, one observer reading on both occasions.

Evidence from Mass Miniature Radiography.One thousand four hundred and sixty-eight large films from eight Durham pits were viewed and classified (Table 6). Six of the pits were in the eastern part of the coalfield and the others in the west and south. Two of the six are coastal and work undersea coal. They were not specially selected but were taken in order, as each request for a visit came from the men. The large films showing pneumoconiosis have been divided into two groups, those showing Category 1 changes only and those

TABLE 5

READINGS OF MIXED SERIES OF FILMS BY CARDIFF (P.R.U.) AND NEWCASTLE OBSERVERS

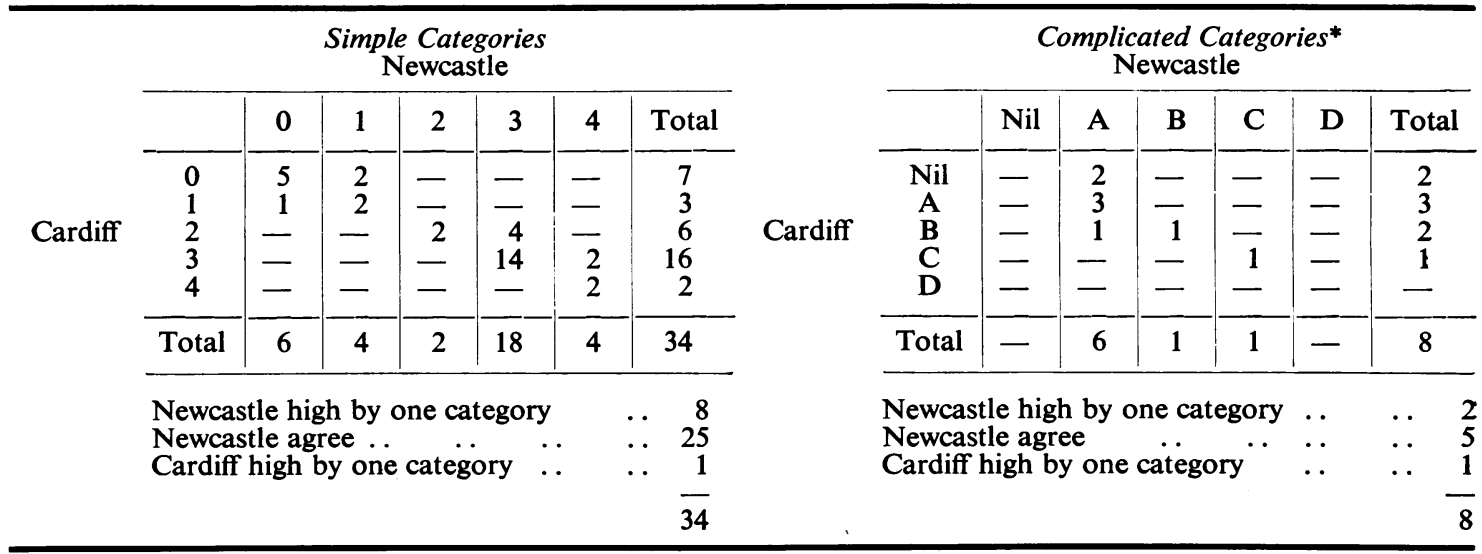

*Each complicated category is also classified 1, 2, 3 or 4. Progressive massive fibrosis (A to D) has been considered separately.

A further comparison was made between readings of a mixed series of films covering all the simple categories and complicated Categories $\mathrm{A}$ to $\mathrm{C}$. There were 34 films and each was classified once in Cardiff and once in Newcastle. Again the Newcastle readings were somewhat higher but there was better agreement in the small number of complicated categories (see Table 5). showing more advanced changes. This has been done because of the greater disagreement we have found among our observers in placing a film in Category 0 or 1. The nature of the sample of miniature film is not accurately known and the errors in selecting men for large films have already been referred to, so that the number of men with pneumoconiosis has been expressed not only as a 
TABLE 6

NUMBER AND PROPORTION OF MEN WITH PNEUMOCONIOSIS IN EIGHT PITS IN COUNTY DURHAM

\begin{tabular}{|c|c|c|c|c|c|c|c|c|c|}
\hline \multirow{3}{*}{ Pit } & \multirow{3}{*}{$\begin{array}{c}\text { Estimated } \\
\text { No. of } \\
\text { Men } \\
\text { Above and } \\
\text { Below } \\
\text { Ground } \\
\text { Dec., 1948 }\end{array}$} & \multirow{3}{*}{$\begin{array}{c}\text { No. of } \\
\text { Miniature } \\
\text { Films } \\
\text { Taken } \\
\text { (Sample) }\end{array}$} & \multicolumn{3}{|c|}{ Large Films } & \multicolumn{4}{|c|}{$\begin{array}{l}\text { Percentage Above and Below Ground } \\
\text { with Pneumoconiosis }\end{array}$} \\
\hline & & & \multirow{2}{*}{$\begin{array}{c}\text { Total } \\
\text { Viewed }\end{array}$} & \multicolumn{2}{|c|}{ Pneumoconiosis } & \multicolumn{2}{|c|}{ Cat. 1 Only } & \multicolumn{2}{|c|}{ Cat. 2 and Over } \\
\hline & & & & $\begin{array}{c}\text { Cat. } 1 \\
\text { Only }\end{array}$ & $\begin{array}{l}\text { Cat. } 2 \\
\text { and Over }\end{array}$ & $\begin{array}{l}\text { In } \\
\text { Sample }\end{array}$ & $\begin{array}{c}\text { Total Men } \\
\text { in Pit }\end{array}$ & $\underset{\text { Sample }}{\text { In }}$ & $\begin{array}{l}\text { Total Men } \\
\text { in Pit }\end{array}$ \\
\hline $\begin{array}{l}\text { A } \\
B \\
\text { C } \\
\text { D } \\
\text { E } \\
\text { F } \\
\text { G } \\
\text { H }\end{array}$ & $\begin{array}{l}1,775 \\
2,659 \\
1,858 \\
2,566 \\
1,335 \\
1,974 \\
1,460 \\
1,736\end{array}$ & $\begin{array}{r}919 \\
1,346 \\
1,057 \\
1,137 \\
811 \\
1,059 \\
715 \\
893\end{array}$ & $\begin{array}{r}159 \\
301 \\
98 \\
273 \\
170 \\
165 \\
147 \\
155\end{array}$ & $\begin{array}{l}26 \\
75 \\
14 \\
80 \\
39 \\
32 \\
27 \\
25\end{array}$ & $\begin{array}{l}68 \\
96 \\
35 \\
61 \\
41 \\
35 \\
61 \\
55\end{array}$ & $\begin{array}{l}2 \cdot 8 \\
5 \cdot 6 \\
1 \cdot 3 \\
7 \cdot 0 \\
4 \cdot 8 \\
3 \cdot 0 \\
3 \cdot 8 \\
2 \cdot 8\end{array}$ & $\begin{array}{l}1 \cdot 5 \\
2 \cdot 8 \\
0 \cdot 75 \\
3 \cdot 1 \\
2 \cdot 9 \\
1 \cdot 6 \\
1 \cdot 8 \\
1 \cdot 4\end{array}$ & $\begin{array}{l}7 \cdot 4 \\
7 \cdot 1 \\
3 \cdot 3 \\
5 \cdot 4 \\
5 \cdot 1 \\
3 \cdot 3 \\
8 \cdot 5 \\
6 \cdot 2\end{array}$ & $\begin{array}{l}3 \cdot 8 \\
3 \cdot 6 \\
1.9 \\
2 \cdot 4 \\
3 \cdot 1 \\
1 \cdot 8 \\
4 \cdot 2 \\
3 \cdot 2\end{array}$ \\
\hline Total & 15,363 & 7,937 & 1,468 & 318 & 452 & $4 \cdot 0$ & $2 \cdot 1$ & $5 \cdot 7$ & $2 \cdot 9$ \\
\hline
\end{tabular}

percentage of the sample but also as a percentage of the total number of men at the colliery. The latter figure represents, therefore, a minimum one.

Assuming that all the films read as Category 1 were in fact normal, at least $1.9 \%$ to $4.2 \%$ of all the men at these eight pits have pneumoconiosis (Category 2 and over), or between $3.3 \%$ and $8.5 \%$ of the sample attending for a miniature film. These are the men with really significant changes. The most conservative estimate of pneumoconiosis, all categories, at these pits would then be between 3\% and $6 \%$ of the total working population. It is impossible to estimate the disability associated with the disease in these men as only a small proportion were examined clinically. However, most of those who were radiographed were actively at work at the time, and our out-patient experience shows that there is little relation between disability and the $x$-ray appearance.
Radiological Type of Disease.-Most of the pneumoconiosis seen in these films was of the simple variety, mainly in the first three categories. Category 4 was not found at all frequently. The number of films placed in each category, and the number considered normal (Category 0), is shown for each pit in Table 7 which shows that the complicated variety is much rarer and is represented in these films mainly in Category $A$ with a few in Categories B and C. There are no films in Category $D$, but we have seen men in this category in our outpatient work, though infrequently. In some cases it has been possible to pick out films which in appearance suggested classical silicosis (second stage) rather than coal workers' pneumoconiosis, and usually on reference to the occupational history a long period of stone drilling has been noted. These films have not been included in the present series.

TABLE 7

LARGE FILMS TAKEN AT EIGHT DURHAM PITS CLASSIFIED BY PIT AND CATEGORY

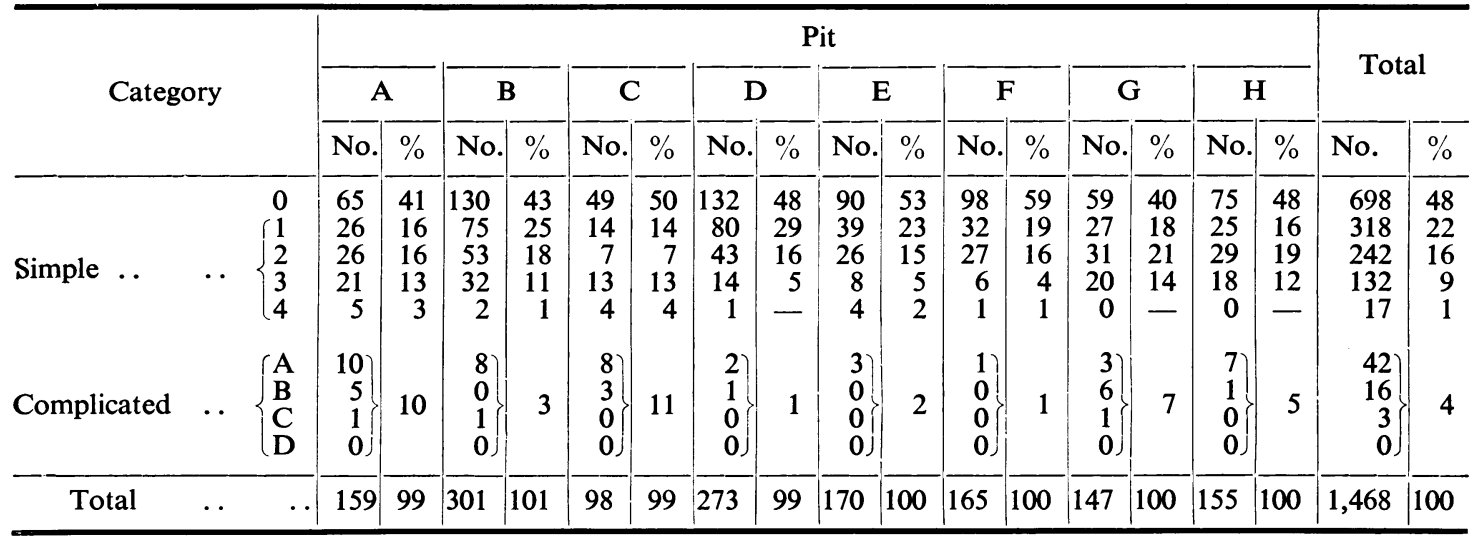


PNEUMOCONIOSIS OF COAL MINERS IN N.E. ENGLAND

TABLE 8

NUMBER AND PERCENTAGE OF MEN IN EACH RADIOLOGICAL CATEGORY BY AGE

\begin{tabular}{|c|c|c|c|c|c|c|c|c|}
\hline \multirow{2}{*}{$\begin{array}{l}\text { Age in } \\
\text { Years }\end{array}$} & \multicolumn{5}{|c|}{ Category } & \multirow{2}{*}{ Total } & \multirow{2}{*}{$\begin{array}{l}\text { Percentage } \\
\text { in Cat. } 1 \\
\text { and Over }\end{array}$} & \multirow{2}{*}{$\begin{array}{l}\text { Percentage } \\
\text { in Cat. } 2 \\
\text { and Over }\end{array}$} \\
\hline & 0 & 1 & 2 & 3 & 4 & & & \\
\hline $\begin{array}{l}14-18 \\
19-23 \\
24-28 \\
29-33 \\
34-38 \\
39-43 \\
44-48 \\
49-53 \\
54-58 \\
59-63 \\
64-68\end{array}$ & $\begin{array}{r}22 \\
45 \\
76 \\
68 \\
120 \\
99 \\
79 \\
76 \\
67 \\
30 \\
8\end{array}$ & $\begin{array}{r}-2 \\
16 \\
19 \\
40 \\
58 \\
74 \\
50 \\
25 \\
24 \\
5\end{array}$ & $\begin{array}{r}- \\
4 \\
7 \\
36 \\
56 \\
38 \\
50 \\
29 \\
25 \\
1\end{array}$ & $\begin{array}{r}- \\
-1 \\
5 \\
22 \\
31 \\
28 \\
37 \\
20 \\
18 \\
6\end{array}$ & $\begin{array}{l} \\
= \\
3 \\
5 \\
6 \\
4 \\
4 \\
1 \\
1\end{array}$ & $\begin{array}{r}22 \\
47 \\
97 \\
99 \\
221 \\
249 \\
225 \\
217 \\
145 \\
98 \\
21\end{array}$ & $\begin{array}{r}0 \\
4 \\
22 \\
31 \\
46 \\
60 \\
65 \\
65 \\
54 \\
69 \\
62\end{array}$ & $\begin{array}{r}0 \\
0 \\
0 \\
5 \\
12 \\
28 \\
37 \\
32 \\
42 \\
37 \\
45 \\
38\end{array}$ \\
\hline Total & 690 & 313 & 246 & 168 & 24 & 1,441 & 52 & 30 \\
\hline Average age & 41 & 46 & 48 & 49 & 48 & 45 & - & - \\
\hline
\end{tabular}

Age and Category

When the men with pneumoconiosis are considered by age and category (Table 8 ) it is seen that, excluding two men in Category 1, all categories occur in men over 24 years of age. Nearly all the men with pneumoconiosis will have done at least six to eight years' underground work which would include four to five years' pneumatic hewing. Below 30 years of age there are few men in Category 2 or 3. Dust changes are more common after the age of 34 years. After 39 to 44 years there is no marked change in the percentage of men with abnormal films in each five-year age group. This may be because men with more advanced pneumoconiosis tend to leave the pit after this age, or because the older men are changing to less dusty work away from the face, for the average age in each category does not vary very much. It is noteworthy that after the age of 54 years about a third of the men show no recognizable dust changes on radiography. The occupational histories of these men did not differ from those who had pneumoconiosis, a fact which suggests a difference in susceptibility.

\section{Discussion}

It is clear from the evidence presented here that there is a fairly widespread prevalence of lung changes due to dust, particularly in the Durham coalfield and probably to a lesser extent in Northumberland. It must be emphasized, however, that so far it appears that the north east reflects only faintly conditions in South Wales, and not only are the numbers of miners affected far smaller than in Wales but also the disease is probably less severe, with perhaps less risk of superimposed tuberculous infection. Nevertheless the pathology of pneumoconiosis in the north east is similar to that in the soft coal areas of South Wales (Duguid, personal communication). In the 40 years since Oliver's reference to the disease there has been no further mention of it in the north east other than a suggestion that there may have been a true increase in incidence of the disease in other coalfields than the South Wales one, though not such a serious increase (Fletcher, 1948).

There may well have been a small incidence of pneumoconiosis in this area after the end of the nineteenth century, but a black lung or " anthracosis" in a coal miner is often accepted as a normal finding, and the complicated form may have been regarded as purely tuberculous. From the clinical standpoint many miners who were, in fact, suffering from the effects of dust inhalation have in the past undoubtedly been considered to have bronchitis, or bronchitis and emphysema. The limitations of ordinary chest radiology have not been sufficiently appreciated, because it has only recently been shown how much individual opinions may differ even where the radiography is of the highest quality (Fletcher and Oldham, 1949). But it is unlikely that a high prevalence of gross pathological change in the lungs of miners in the north east would have passed unnoticed, particularly in institutions such as the Royal Victoria Infirmary in Newcastle upon Tyne where a fifth of adult male admissions are coal miners.

Greenhow's (1866, 1869) and Oliver's (1908) description of black lungs in the north east between 1860 and 1880 were after the modern development of the Durham coalfield and its greatest expansion. 
But at the same time improvements in ventilation were being introduced, largely because of mine gases and the risk of explosion. Because of the long natural history of pneumoconiosis it seems reasonable to link these facts and to correlate the early expansion of the coalfield with the evidence of gross pneumoconiosis 20 or 30 years later. This was before mechanization, and only the hand pick was used in the coalfield, so that ventilation was probably the main factor involved. The improvements in ventilation which followed closely deeper and more extensive mines probably sufficed to reduce dust concentration to a level low enough to make pneumoconiosis a rarity for the time being. It seems likely that increased dustiness from mechanization has reversed this trend over the last 30 years, and that ventilation has not always kept pace with the increase in the depth and extent of the pits.

Although relatively a small problem compared with that in some of the other coalfields in Britain, pneumoconiosis in Durham is now of considerable local importance and its full implications must still be assessed. The present data, derived from the work of a mass radiography unit in certain pits in Durham, despite their limitations, give the most complete information which is at present available.

\section{Conclusion}

There seems to be no reason to fear the results of pneumoconiosis surveys, because the miners themselves know that the disease occurs, and on the whole welcome an attempt to investigate it. Mass radiography in a mining area must be prepared in advance to deal with pneumoconiosis. In Durham it was arranged that men could be referred to the Nuffield Department of Industrial Health through their own doctors, if further advice was required. In advising men with pneumoconiosis, an attempt is made to counteract the psychological ill-effects of the diagnosis by explanation and reassurance.

As these results suggest that the Newcastle observers have tended to read too high, though not consistently, the minimum figures for the total of all categories at each pit may be considered to be too high and misleading. Films placed in Category 1 and also some in Category 2 would probably be found to include some normal films if they were re-read, or read by different observers. The present definition of the lower limit of simple pneumoconiosis may need to be revised, as even skilled observers occasionally diagnose early Category 1 changes in men without dust exposure (Fletcher and others, 1949). A more accurate assessment might be made by increasing the number of observers or observations, that is by re-reading the films until a consistent result was obtained. The latter requires. great time expenditure and the former a considerable number of experienced staff. In both cases films of first class quality are desirable.

It is clear that complete surveys of several representative pits throughout the coalfield, in which all the working population or at least all the underground population are examined with large films, are required to amplify these figures, and one such survey has by now been carried out. Preliminary results suggest that the figures in this paper underestimate the prevalence of pneumoconiosis. Miniature mass radiography is of doubtful value as far as pneumoconiosis is concerned, as it will only detect the grosser forms with certainty and gives little idea of the prevalence of simple dust retention in the men's lungs. From the preventive aspect it is important to gain a complete picture of the prevalence at a particular pit and at present it appears that this can only be done by using full size $x$-ray films. On the other hand, when a visit from the M.M.R. unit has been requested by men at a colliery this should be made as for other industrial groups, and every effort made to detect cases of open tuberculosis in view of the relation between this disease and pneumoconiosis (Mann, 1951).

The evidence so far suggests that the larger and deeper coastal pits have been very dusty during the past two or three decades and any further mechanization or any falling off in the efficiency of their ventilation is likely to make them dustier still. A higher incidence of pneumoconiosis will be the inevitable result unless dust suppression (already in use in some Durham pits) is further extended, and it will be required in all pits which are actively developing and ultimately in all faces where any form of mechanized coal-getting is used.

\section{Summary}

Pneumoconiosis of coal miners has, in the past, occurred in a gross form in north east England following a period of expansion in the coal industry. Improvement in ventilation probably reduced the clinically recognizable disease to small proportions towards the end of the nineteenth century and beginning of the twentieth.

Mechanized coal-getting has probably increased the true prevalence of pneumoconiosis, but diagnosis has also improved. The changes in the lungs of Durham miners appear to be similar to those found in the soft coal area of South Wales except that they are less severe.

Evidence from routine mass miniature radiography at eight Durham pits suggests that a minimum of $3 \%$ to $6 \%$ of men in these pits show well marked pneumoconiosis.

Future developments in the coalfield will tend to 
intensify dust production and the risks of pneumoconiosis unless dust suppression methods are considerably extended.

Acknowledgments are due to Professor R. C. Browne for help with this paper ; to Dr. D. M. Calvert, Medical Director, Mass Radiography Unit, Durham, and the Regional Hospital Board, No. 1 Region, for their cooperation in obtaining and viewing films, and to the staff of the unit for their help in obtaining occupationd histories ; also to the National Union of Mineworkers, Durham Area, for their assistance, and to $\mathrm{Mr}$. $\mathbf{H}$. Campbell for statistical help.

\section{REFERENCES}

Browne, R. C., Beck, I. F., and McCallum, R. I. (1949). Brit. J. soc. Med., $3,77$.

Cochrane, A. L. (1951). (Proceedings of Conference) "The Application of Scientific Methods to Industrial and Service Medicine," p. 97. Med. Res. Coun. H.M.S.O. London, March 1950.
Davies, I., and Mann, K. J. (1949). Proc. 9th Int. Congr. Industr. Med. London. 1948, p. 768. Bristol.

Duguid, J. B. Personal communication.

Evelyn, J. (1661). " Fumifugium." Colburn, London, 1825.

Fletcher, C. M. (1948). Brit. med. J., 1, 1015, 1065.

-, and Gough, J. (1950). Brit. med. Bull., 7, 42.

-, and Mann, K. J., Davies, I., Cochrane, A. L., Gilson, J. C., and Hugh-Jones, P. (1949). J. Fac. Radiol., Lond., 1, 40. and Oldham P. D. (1949). British Journal of Industrial Medicine, 6, 168.

, and Oldham P. D. (1951). Ibid. 8, 138.

Greenhow, E. H. (1866). Trans. path. Soc. Lond., 17, 36.

(1869). Ibid. 20, 41

Gregory, J. C. (1831), Edinb. med. surg. J., 36, 389.

Hart, P., D'Arcy, and Aslett, E. A. (1942). Spec. Rep. Ser. med. Res. Coun. Lond., No. 243.

Mann, K. J. (1951). Thorax, 6, 43.

McVittie, J. C. (1949). Postgrad. med. J., 25, 618.

National Union of Mineworkers (1948). General Secretary's Annual Report. (Durham Area.)

Nef J. U. (1932). "The Rise of the British Coal Industry." London.

Oliver, T. (1908). "Diseases of Occupation." (3rd Ed. revised 1916). London.

Retief, F. (1946). Proc. Transv. Mine med. Offrs' Ass., 26, 39

Simon, J. (1862). 4th Rep. med. Offr. Privy Coun., Lond., 1861. P. 21. Smith, W. (1949). "An Economic Geography of Great Britain." London.

Stratton, T. (1838). Edinb. med. surg. J., 49, 490.

Thomson, W. (1837). Med-chir. Trans., 20, 230. (Abstract in Edinb. med. surg. J., 1838, 49, 260.) 